\title{
A Proposed Pan Layer Classification for Soils of Suez Canal Area, Egypt
}

\section{El-Sayed E. Omran}

Soil and Water Department, Faculty of Agriculture, Suez Canal University, 41522, Ismailia, Egypt. E-mail: ee.omran@gmail.com

Department of Natural Resources, Institute of African Research and Studies, Aswan University 


\section{Abstract:}

Pan layers are among the most common land-use limiting factors in the Suez Canal area. Much of the agricultural land degradation in this area is a result of the existence of hardpan layers. In the literature, various types of pans were distinguished including indurated or cemented pans, claypans, and fragipans. Pan layers are further classified into the natural pans and anthropogenic pans. Depending on the type of cementation, natural pan is subdivided into different types; claypans, fragipans, indurated layers, cemented by iron, silica, lime, gypsum or humus. Anthropogenic pans are graded into tillage pan, surface crust and finally the pasture pan produced as a result of grazing animals packing action. Not all of the key pan layer classifications are ideal for mitigating their land-use hazards since little information is available. So, to address their hazards in agricultural production, intensive characteristics, geographic distribution, and classification of these hardpan layers are required.

So, a new classification was suggested for the pan layers of arid and semi-arid areas. Samples collected from the soil and associated pan layers were subjected to physical, chemical, mineralogical, micro-morphological and unconfined analysis of compressive strength. The proposed classification is based on qualitative field clues and quantitative laboratory data, including degree of slaking, classes of particle size distribution, cementing 
materials, level of induration, unconfined compressive strength, thickness, regime of soil moisture, classes of mineralogy, and depth. Hardpan layers are thus categorized into 25 families. This new proposed classification revealed various types of pan layers differing in their range of texture, mineralogy, depth thickness, hardness, and humidity. This knowledge can thus help to suggest an appropriate guide to the best agricultural use of soils.

Therefore, it is recommended that all reclamation areas should be examined before their cultivation to avoid many problems that concerning presence of the pan layers near the surface that results in an increase in soil salinity and a rise in the ground water level. Decision-makers should also pay close attention to focus efforts to study these problems and minimize their adverse effects on agriculture.

Keywords: Pan layer, Petropan, Nonpetropan, Indurated, Hardpan, Claypan, Pan Classification.
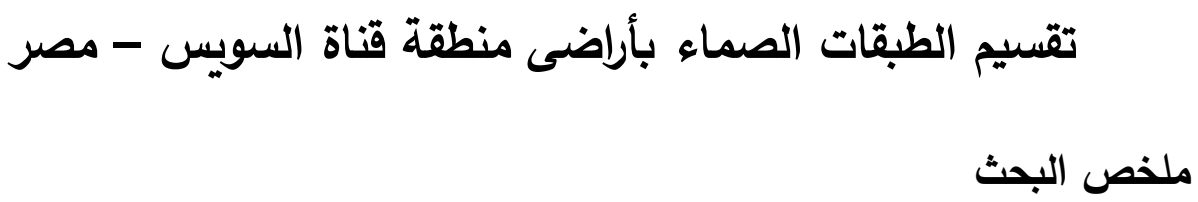

تعتبر الصبقات الصماء والمتصلبة التى توجد على أعماق مختلفة بالتربة من أكثر المشاكل خطورة على الإستغلال الزراعى ، لقد تسببت فى تدهور كثير من الأراضسى بمنطقة قنساة

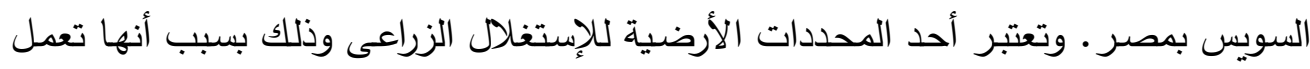

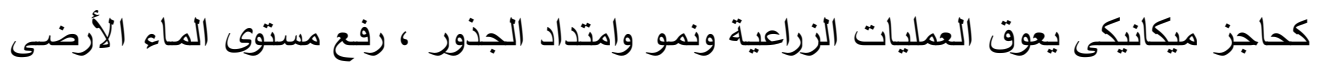

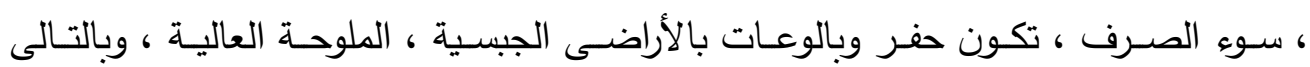

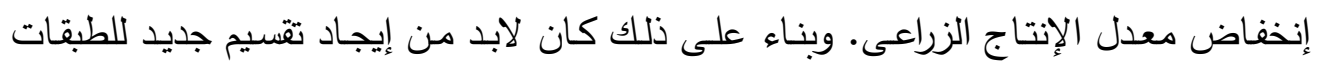


الصماء بحيث يمكن الإستفادة به من الناحية التطبيقية ، خاصة وأن معظم التقسيمات القديمة تقليدية ولاتصلح للنواحى التطبيقية.

ولقد تم حفر قطاعات تربة بالمواقع المختلفة التى تمثل الأنواع الرئيسية للطبقات الصماء

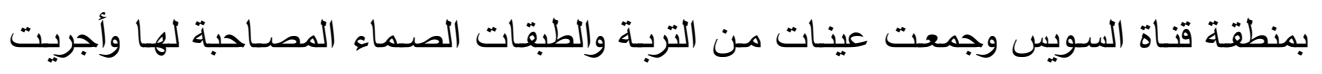
عليها التحليلات الكيميائيـة ، الفيزيائيـة ، المنرالوجيـة ، الصـلابة والميكرومورفولوجيـة. وبنـاء

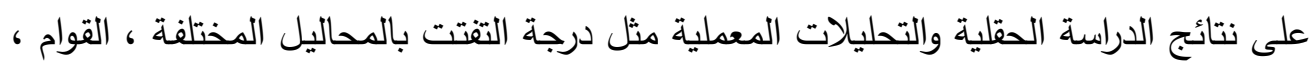

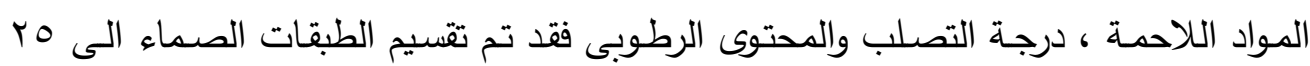

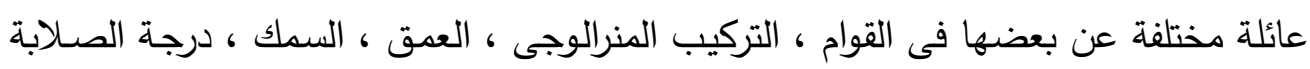

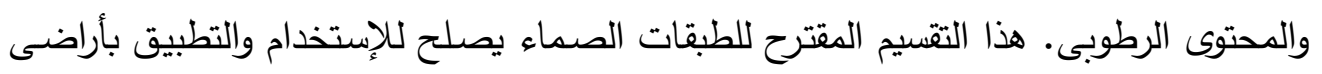

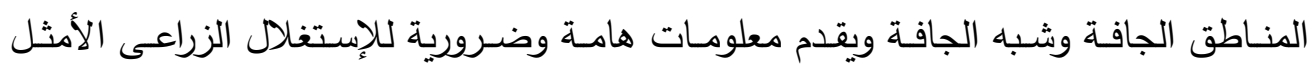
بالمناطق الصحراوية.

وبناء على ذلك نوصى بدراسـة جميع مناطق الإستصـلاح قبل البدء فى زراعتها حتى

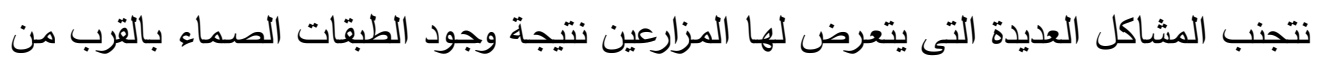

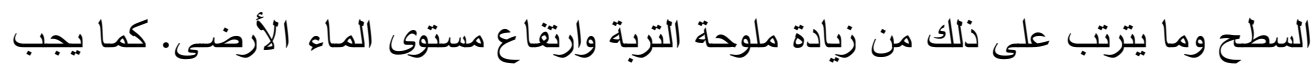
على المسئولين الإهتمام الثديد وتركيز الجهد لدراسة هذه المشاكل والتقليل من آثارها الضـارة

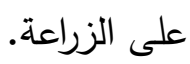

\section{INTRODUCTION}

Given the widespread pan layers, relatively little knowledge is available in large areas of agronomic significance in Egypt. In the past, most of the researchers had only been concerned with surface soil layer. Little importance was attached to the role of pan layers in crop production. Currently the hardpan layers have been given more attention by scientists. Growing awareness of the value of pan layers to farm is encouraging people to look for knowledge about their properties. 
Pan layers are among the most common land-use limiting factors in the Suez Canal zone. It is important to note that most of the agricultural land degradation in the Suez Canal area is developing pan layers. They might restrict the chances of agricultural practices, root production, and penetration, due to their induration and hardness. Claypans, gypsum pans and caliche are the most common pans at various sites in Egypt (El-Mowelhi and Hamdi,1975; Gendy, 1976; El-Araby and Hussein, 1984.

Soil horizons are layers also called pans (winter and Simonson, 1955), which are tightly compacted or indurated. On the one hand, the Soil Survey Staff (1951) distinguished three main types of pans, namely: indurated or cemented pans, claypans, and fragipans. On the other hand, pan layers are classified into induced pans and natural pans (Winter and Simonson, 1955). Induced pans are apparently the results of a recently applied compacting force such as implement, traffic or trampling upon soil. Natural pans are like claypans, fragipan, caliche, and iron-silicia pans. Moreover, the pan layers are classified into natural pans and anthropic pans (Roy, 1963). Natural pans are subdivided into various types depending upon the kind of cementation; claypans, fragipan, indurated layers which are cemented by iron, silica, lime, gypsum or humus. Anthropic pans are classified into tillage pan, surface crust and finally the pasture pan formed as a result of packing action of grazing animals. 
Little attention was paid to the role of the hardpan layers in crop production in the Suez Canal area. Since little information is available, all these primary classifications of pan layers are not sufficient to mitigate their hazards to land-use. Therefore, it is important to intensively investigate the characteristics, geographic distribution and classification of these hardpan layers to address their hazards in agricultural production. So, the classification of pan layers at the family level is of an urgent need for efficient crop production and to assist in suggesting suitable recommendations for the soil suitability to grow crop plants.

The current paper aims to propose a new classification for hardpan layers in the Suez Canal area. This classification depends upon the quantitative laboratory investigation based on a variety of qualitative field clues.

\section{HARDPANS AS A SOIL LIMITATION}

Subsurface hardpan layers hinder the growth of the plant roots that difficulty penetrate these rigid (indurated) layers, and cause low water drainage resulting in high water table and salinity levels. The term hardpan is frequently misused to describe any poorly drained or hard-working soil. The roots of plants do not grow inside the hardpan. The hardpan is considered as a rock, and neither roots nor water can penetrate it. To determine if a material is a hardpan or just a very hard soil, a chunk should be broken off and submerged in water. If the water is consumed, it will be a hard 
soil. When the water is not drained, it would, therefore, be a hardpan. Hardpans are one of the principal causes of waterlogged areas. The literature distinguishes four key explanations for waterlogging, namely (1) the creation of a perched aquifer over an extendable layer of clay (pan) over high table lands, (2) the topographic relief of changes and flooding of many micro depressant zones in low lying areas, (3) the practice of irrigation, and (4) the canal flow. The depth to the pan layers mostly plays the important role in creating the problem. Using excess water recharging from the irrigation distribution network results in slowly rising the groundwater table and causing waterlogging. Excess soil moisture produces salinity, and is adversely affected by plant development due to poor aeration in.

Hardpan soil is a soil characterized by a rock-hard layer of material that is close enough to the soil to limit the depth of plant roots and stop the soil internal drainage. The hardpan depth varies from a few centimeters to two or three meters from the soil surface. It may be of good texture and have a good structure which makes it easy to work - or it may be of poor texture, dense and hard making it very hard to work. Only the problems of the hardpan causes need to be addressed in areas where the soil above the hardpan is easy to work. If the soil above the hardpan is dense and hard, this problem, in addition to those caused by the hardpan, should also be considered. Roots cannot be developed into the 
hardpan. Therefore, the soil above the hardpan is confined to root growth. Due to the limited amount of soil that crops can get nutrients and water from, plant growth may be restricted. Many trees and shrubs may be prevented from creating a root system large enough to keep them in place during heavy wind, especially when the soil is very moist. The hardpan cannot penetrate water. Therefore, the soil above it can easily become waterlogged, because the excess water cannot be drained to lower depths. Waterlogged soil has very little, if any, air in it. Most crop roots do not function reliably in the soil without oxygen, and quickly die in a very wet soil. Identified five major factors that are responsible for the issue of water logging and salinity at ElDakhla basin. Hardpan occurrence is the main of factor that causes waterlogging and salinity problems in this area. There are different kinds of hardpans in this area such as claypans and clacipans, which share the common characteristics of being a distinct soil layer that is largely water impermeable. Some hardpans are produced by soil deposits that fuse the soil particles and bind them together. These deposits vary from dissolved silica to iron oxide and calcium carbonate forming matrices. Caliche is sedimentary rock that connects other materials such as gravel, sand, clay, and silt. The claypan is a dense, compact, slowly permeable layer in the subsoil, which it has higher clay content than the surrounding material from which it is divided by a clearly 
defined boundary. It is normally hard when dry, and soft and sticky when wet. It limits or slows down water movement through the soil.

Farafra oasis is one of the most marginalized villages in Egypt that is an extreme example of Egyptian land reclamation and resettlement policies. Nevertheless a new society of settlers faces many of the same problems faced by other new settler groups in Egypt. Farafra oasis faces serious water table problems at different depths due to over-irrigation and hard pans at various depths. From an environmental point of view, poor land management in Farafra oasis is a serious concern and poses a serious problem for water quality and soil, since the latter is a non-renewable resource in the area. Preventing adverse effects on wetlands is simple if the land in question is recognized as a wetland at the start of the planning phase.

Claypans and clacipans in Farafra oasis share the overall characteristic of being a distinct soil layer that is mostly waterpervading. Some hardpans are formed by fusing soil deposits and binding soil particles. Such deposits can range from silica dissolved to iron oxide, and matrices containing calcium carbonate. Nevertheless, due to the lack of adequate studies compiled during the planning phase itself, the soil resources and crop pattern of the area led to large-scale land degradation due to waterlogging and subsequent salinization. With respect to the 
natural variables, such as topographical depressions, the lack of natural drainage and incessant rain further compounds the waterlogging and salinity issues. The underground sequence of the recently grown fields in the Farafra oasis revealed the pattern of buried alluvial channels, which are waterlogged and described by diagnostic saline shrubs development. Satellite images indicate that the water ponds in the downstream of these channels partially occupy the ground playas. When planning new cultivation in dry land catchments, consideration must be given to the geomorphology of closed drainage basins in order to better manage the waterlogging danger. Farm management and water conservation for irrigation, salt leaching, and evapo-transpiration are also crucial to reduce the increase in waterlogging. Waterlogging and soil salinity can be managed by maintaining a net salt flow away from the root zone and by regulating the water level through drainage systems. By building artificial drainage, including both open surface drains and underground drainage pipes, it can be accomplished to maintain a balance between soil recharge and release by draining the surplus soil water table.

\section{MATERIALS AND METHODS}

\subsection{Description of the Area}

Most of the area under consideration, which lies between the eastern branch of Nile Delta and the Suez canal as well as a relatively strip of land in the East Bitter Lakes area are located at a 
low topographic position growing from zero to about $100 \mathrm{~m}$ above sea level (Figure 1). The present arid climatic conditions, which evaporation exceeds precipitates, have its imprints on the soils and landforms. It is clear in the formations of sabkhas and saline soils, desert pavement, evaporate deposits of gypsum, and sand dunes. Contrary to the land features related to aridity, there are also important features related to the wet paleoclimatic conditions (Shata, 1997). They are represented by the dry wadis and the occurrence of reddish soil of old terraces. The Suez Canal region is essentially occupied by sedimentary rocks belonging to the Quaternary deposits resting uncomfortably on the different rock units of the Tertiary (El-Fayoumy, 1968; Said, 1990). The rock exposures (sandstone, limestone, shale and gypsum) are essentially covered with young unconsolidated deposits of varying mode of formation including, faluviatile, lagoonal and aeolian. These deposits form most of the soil parent materials in the Suez Canal region. The study area is a part of the east of the Nile Delta region which is classified to eight landforms (Shata, 1978) incuding, structural plateau, structural plain, old deltaic plain, young deltaic plain, lacustrine plain, coastal plain, clysmic plain, and elevated sand sea plane.

The main soil sub-groups which associate with pan layers, namely Typic Hapolgysids, Aquic petrogyspids, Typic petrogypsids, Typic calcigypsids, Calci petrogepsids, Typic Hoplosalids, Typic 
petrogypic Haplosalids, Typci petrocalcids, Typic Torripsamments and Typic Torriorthents (Omran, 1996).

\subsection{Experimental Methods}

Khalifa, East Bitter Lakes, Sarabium, Suez and New Salhia. The chosen sites are covered by a wide variation of pan layers types.

The collected samples from 17 selected soil profiles (Figure 1) were air-dried, crushed and passed through a $2 \mathrm{~mm}$ sieves. Undisturbed samples were collected in Kubiena boxes for thin section preparation. Electrical conductivity (soil paste), gypsum content using the precipitation method by acetone (Richards, 1954), carbonate by the manometric method (Page et al., 1982), cation exchange capacity using ammonium acetate method (Jackson 1975) were determined in the collected samples.

Free iron oxides were extracted according to Mehra and Jackson (1960) and silica and alumina were separated according to Hashimoto and Jackson (1960). Aslaking experiment was carried out by placed air-dry clods of pan layers in water, $1 \mathrm{~N} \mathrm{HCl}, 1 \mathrm{~N}$ $\mathrm{NaOH}$ and dithionite-citrate-bicarbonate (DCB) solution according to Mckeage and Sprout (1975), the solution was extracted after two weeks and certain elements were determined as follows; $\mathrm{Fe}, \mathrm{Mn}$ and $\mathrm{Al}$ in $\mathrm{DCB}$ extract, $\mathrm{Ca}, \mathrm{Mg}, \mathrm{Fe}, \mathrm{Mn}, \mathrm{Al}$ and $\mathrm{Si}$ in water extract, $\mathrm{Al}$, and $\mathrm{Si}$ in $1 \mathrm{~N} \mathrm{NaOH}$ and $\mathrm{Ca}, \mathrm{Mg}, \mathrm{Fe}$ and $\mathrm{Al}$ in $1 \mathrm{~N} \mathrm{HCl}$ extract. Aluminum and $\mathrm{Si}$ were determined 
calorimetrically while $\mathrm{Ca}, \mathrm{Mg}, \mathrm{Fe}$ and $\mathrm{Mn}$ were determined by atomic absorption.

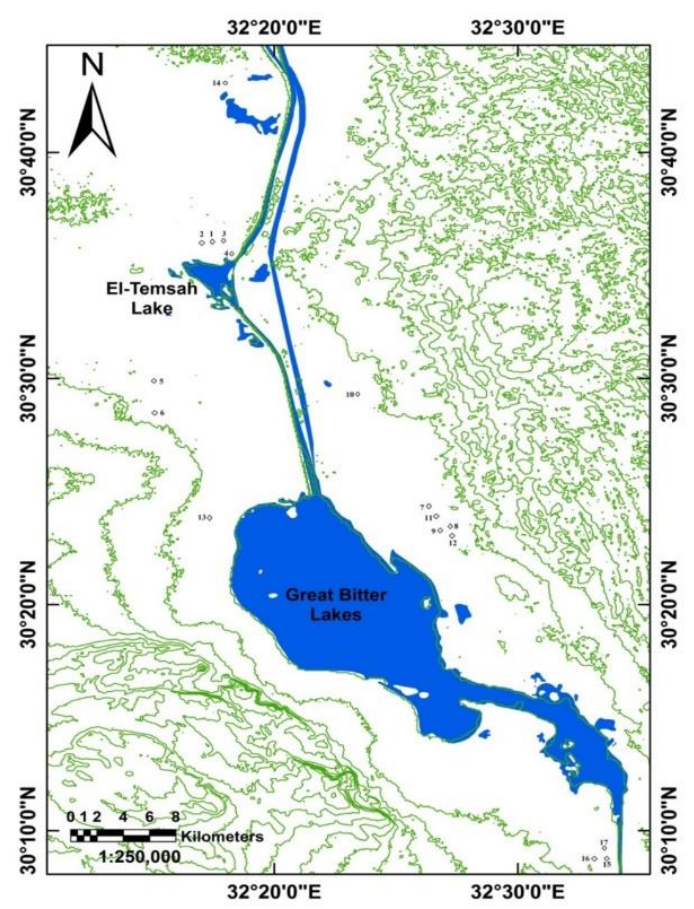

Figure 1 Location of the studied soil profiles.

Bulk density was determined using the paraffin wax method (Black 1965). An unconfined compressive strength test on an airdry and a wet specimen was determined (Franklin and Dusseault, 1989). Thin sections of the undisturbed samples were prepared using a polarizing microscope and nomenclature of observed features followed those proposed by Brewer (1976) and Fitzpatrick (1984) were used.

\section{RESULTS AND DISCUSSION}

The proposed classification of pan layers in the Suez Canal region is based on qualitative and quantitative parameters including 
degree of slaking, particle size classes, cementing material, degree of induration, unconfined compressive strength, thickness, soil moisture regime, mineralogy classes and depth. Figure 2 shows the representative soil profiles and their associated pan layers of the study area. The pan layers can be classified into 3 groups, including petropan, non petropan, and clay pan based on slaking in water. Each pan group is subdivided into subgroups according to the nature and cement materials. Each subgroup could be classified into different pan families. Figure 3 shows hand specimens of pan layers from the soils of the Suez Canal region. There are different criteria were used to differentiate between pan layers.

a) Family differentiation for pan layers: To distinguish families of the pan a layer, within a subgroup, the following differentiates including particle size classes, mineralogical classes, depth classes and moisture regime of pan layers are used according to the Soil Survey Staff (2014).

b) Thickness class: Very thin $(10 \mathrm{~cm})$, moderately thin $(10-$ $20 \mathrm{~cm})$, thin $(20-30 \mathrm{~cm})$, slight thick $(30-60 \mathrm{~cm})$, moderately thick $(60-90 \mathrm{~cm})$, thick $(90-120 \mathrm{~cm})$ and very thick $(>120 \mathrm{~cm})$. 
c) Unconfined compressive strength $\operatorname{classes}^{1}$ : a) Nonindurated pans including slightly hard (< 200 psi), moderately hard (200-400 psi), hard (400-600 psi), very hard (600-800 psi) and extremely hard (>800 psi). b) Indurated pans including slightly indurated (<100 psi), moderately indurated (1000-1500 psi), strongly indurated (1500-2000 psi) and very strongly indurated (> 2000 psi). 

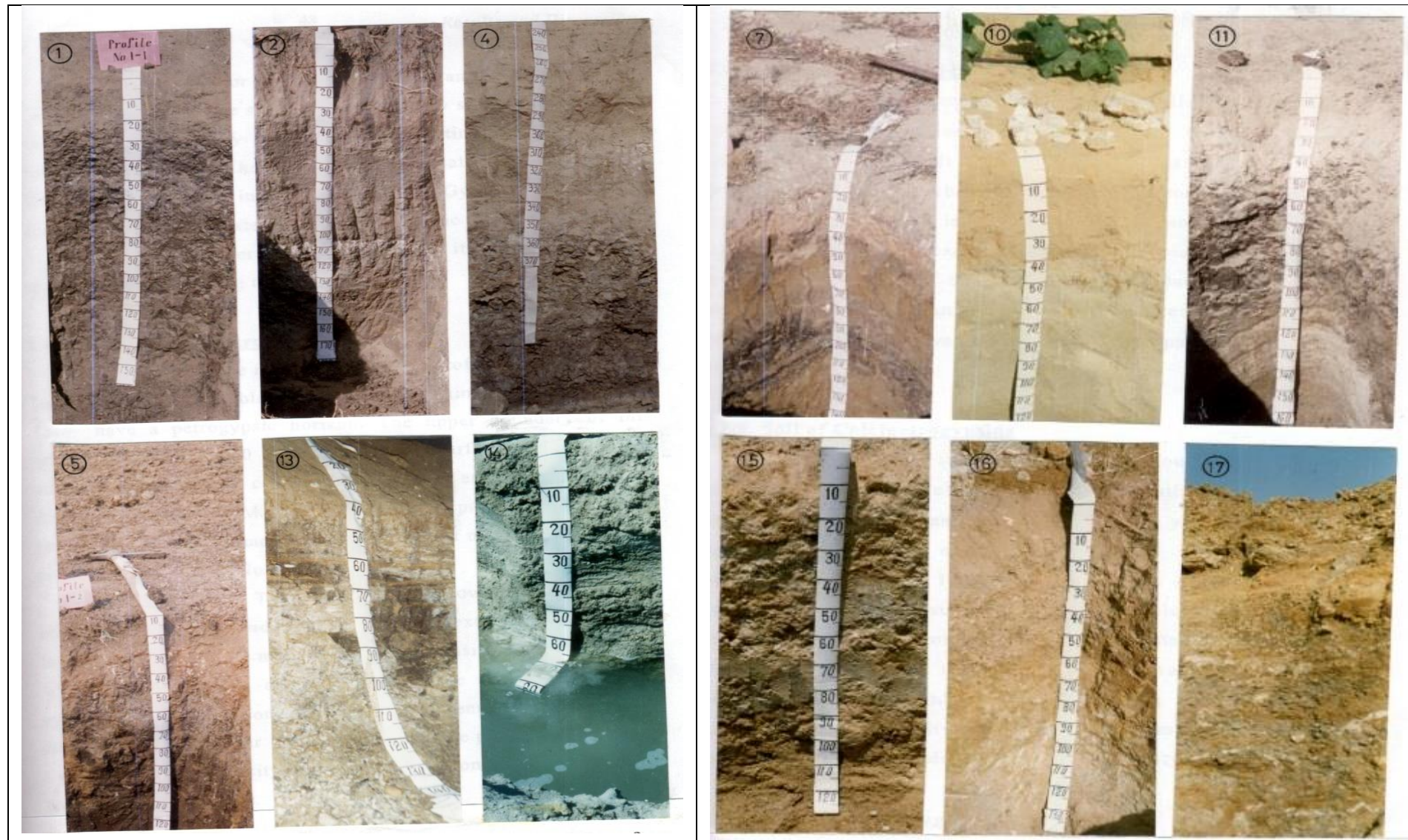

Figure 2 The representative soil profiles and their associated pan layers of the study area

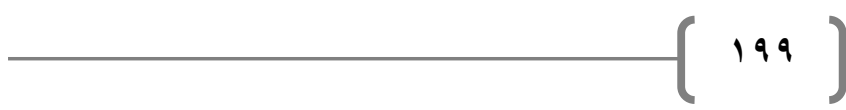


مجلة البحوث والدراسات الأفريقية ودول حوض النيل - جامعة أسوان - المجلد (Y) العدد (ץ) يونية (•r • م م)

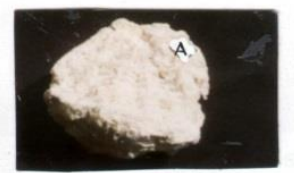

(pr. 14, Cymg2)

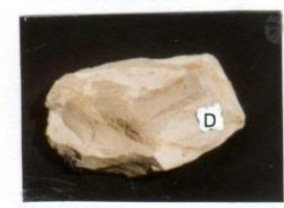

(pr. 17, Cymz2)

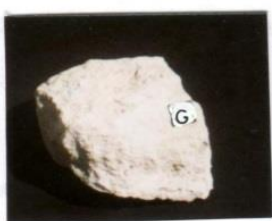

(pr. $4, \mathrm{Ckm} 2)$

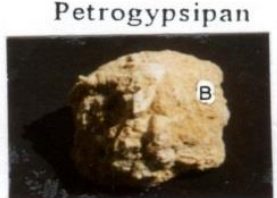

(pr. 15, Cym2)

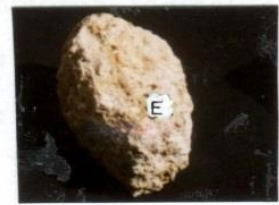

(Suez)
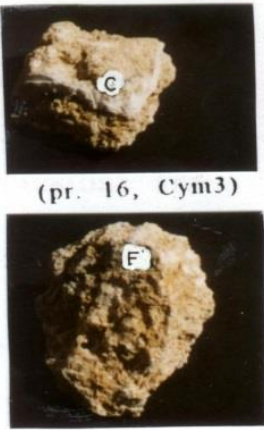

(Suez)

Petrocalcipan

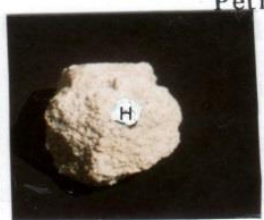

(pr. 9, Ckm2)

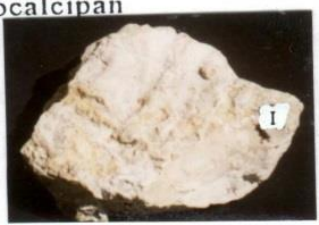

(Pr. 10, Ckm 1)

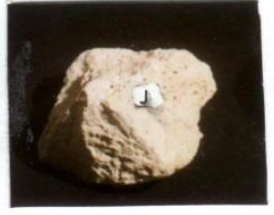

(Suez)

Petrogypsiferromanganipan

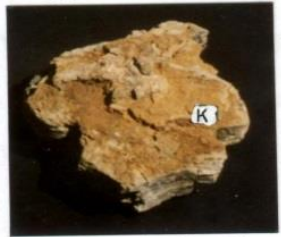

(pr. 7, Cym 3)

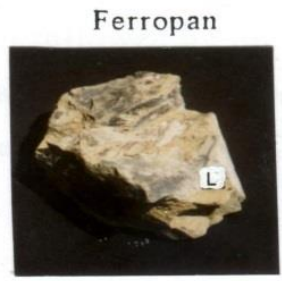

(pr. 7, C1)

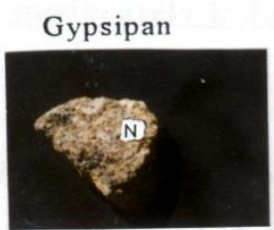

(pr. 16, C2)

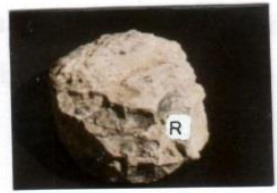

(pr. $4,2 \mathrm{C} 3$ )

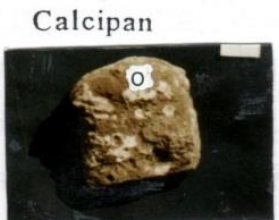

(pr. 5, Ckl)

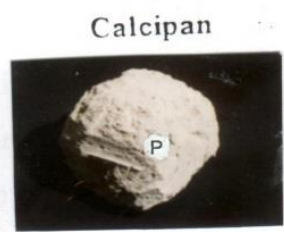

(pr. 14, Czg3)

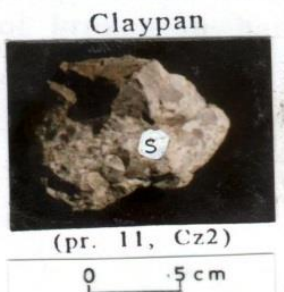

Ferromanganipan

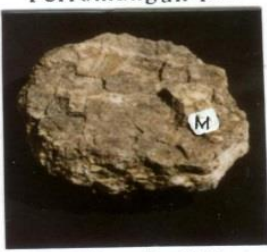

(pr. $7, \mathrm{C} 2)$

Calcigypsipan

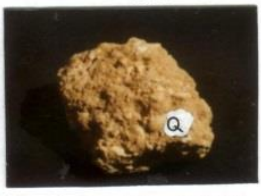

(pr. 16, Ck1)

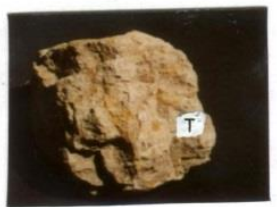

(pr. 13, 2Cz2)

Figure 3 Hand specimens of the pan layers collected from the soils of Suez Canal area. 


\subsection{Pan families of petropan group.}

These pan layers are indurated and do not slake in water. Petropan group is subdivided according to the type of cement material into three main subgroups; petrogyspipan, petrocalcipan and petrogypsiferromanganipan. Ten pan families (Six Petrogypsipan and four Petrocalcipans families) are distinguished within the petropan group (Table 1 and Figure 4).

4.1.1 Petrogypsipan, sandy, gypsic, shallow, slightly thick, moderately indurated aquic: This pan is a petrogypsic horizon with aquic moisture regime. Bulk density is relatively high and unconfined compressive strength reached 1430 psi in the air dry closed as decreased to $1018 \mathrm{psi}$ in water saturated specimens.

This highly gypsiferous pan is of geogenetic origin as well as allogenic and bedrock gypsum occurs with secondary euhedra (lens shaped) gypsum crystals of pedogentic origin. Micromorphological examination of this section reveals a gypsic matrix, gypsans, crystallaria and many pedogenic euhedral gypsum grains (Fig. 4, a-d). Pedogenic gypsum is distinguished from inherited gypsum by the shape and position in soil fabric (Carter and Inskeep, 1988). Inherited (non-pedogenic) gypsum occurs as plasma concentrations (bedrock gypsum), completely filling voids (joint and skewplanes) or as anhederal grains. Pedogenic gypsum of euhedral grains is reported in the same soil. 
Table 1 A new classification for pan layers in Suez Canal area

\begin{tabular}{|c|c|c|c|c|c|}
\hline $\begin{array}{l}\text { Profile } \\
\text { No. }\end{array}$ & Horizon & $\begin{array}{l}\text { Depth } \\
(\mathrm{cm})\end{array}$ & Location & $\begin{array}{c}\text { Pan } \\
\text { sub- } \\
\text { group }\end{array}$ & Pan families \\
\hline \multicolumn{6}{|c|}{ 1. Petropan group } \\
\hline 14 & Cymg2 & $40-90$ & Abu-Khalifa & 1 & $\begin{array}{l}\text { Petrogypsipan, sandy, gypsic, shailow, slightly thick, } \\
\text { moderately indurated aquic. }\end{array}$ \\
\hline 15 & Cym2 & $60-88$ & Suez & 2 & $\begin{array}{l}\text { Petrogypsipan, loamy, gypsic, moderately shallow, thin } \\
\text { moderately indurated, torric. }\end{array}$ \\
\hline 16 & Cym3 & $53-94$ & Suez & 3 & $\begin{array}{l}\text { - Petrogypsipan, sandy, gypsic, moderately shallow, sligl } \\
\text { thick, moderately indurated, torric. }\end{array}$ \\
\hline 17 & Cyzm2 & $40-90$ & Suez & 4 & $\begin{array}{l}\text { - Petrogypsipan, clayey very fine, montmorrillinitic; } \\
\text { moderately shallow, thick, moderately indurated, torric. }\end{array}$ \\
\hline 17 & Czm3 & $90-200$ & Suez & 5 & $\begin{array}{l}\text { Petrogypsipan, clayey very fine, montmorrillinitic; } \\
\text { moderately shallow, thick, moderately indurated, torric. }\end{array}$ \\
\hline 3 & $\mathrm{Ckm4}$ & $145-180$ & Ismailia & 6 & $\begin{array}{l}\text { Petrocalcipan, loamy, mixed, deep, slightly thick, strons } \\
\text { indurated torric. }\end{array}$ \\
\hline 4 & Ckm2 & $320-360$ & Ismailia & 7 & $\begin{array}{l}\text { - Petrocaicipan, loamy, mixed, very deep, slightly thick. } \\
\text { strongly indurated, torric. }\end{array}$ \\
\hline 9 & Ckm2 & $85-115$ & $\begin{array}{l}\text { East-Bitter } \\
\text { lake }\end{array}$ & 8 & $\begin{array}{l}\text { - Petrocalcipan, sandy, mixed, moderately shallow, slight } \\
\text { thick, very strongly indurated, torric. }\end{array}$ \\
\hline 10 & Ckm1 & $30-45$ & $\begin{array}{l}\text { East Bitter } \\
\text { lake }\end{array}$ & 9 & $\begin{array}{l}\text { - Petrocalcipan, loamy, carbonatic, shallow, moderately t } \\
\text { very strongly indurated, torric. }\end{array}$ \\
\hline 7 & Cym3 & $99-108$ & $\begin{array}{l}\text { East Bitter } \\
\text { lake }\end{array}$ & 10 & $\begin{array}{l}\text { Petrogypsiferromanganipan, loamy, mixed, moderately } \\
\text { shallow, very thin, torric. }\end{array}$ \\
\hline \multicolumn{6}{|c|}{ 11. Non-petropan group } \\
\hline 7 & $\mathrm{C} 1$ & $30-85$ & $\begin{array}{l}\text { East bitter } \\
\text { lake }\end{array}$ & 11 & $\begin{array}{l}\text {-Ferropan, clayey very fine, montmorrillinitic, shallow, sli } \\
\text { thick, extremely hard, torric. }\end{array}$ \\
\hline 7 & $\mathrm{C} 2$ & $85-99$ & $\begin{array}{l}\text { East Bitter } \\
\text { lake }\end{array}$ & 12 & $\begin{array}{l}\text { - Ferromanganipan, clayey fine, montmorrillinitic, modere } \\
\text { shallow, moderately thin, moderately hard, torric. }\end{array}$ \\
\hline 5 & Cy2 & $33-57$ & Salhiya & 13 & - Gypsipan, loamy, mixed, shallow, thin, torric. \\
\hline 5 & Ck1 & $14-33$ & Salhiya & 14 & $\begin{array}{l}\text { - Calcipan, loamy, mixed, very shallow, moderately thin, I } \\
\text { torric. }\end{array}$ \\
\hline 1 & $\mathrm{C}_{21} 1$ & $15-103$ & Ismailia & 15 & $\begin{array}{l}\text { - Claypan, clayey fine, mixed, very shallow, moderately } t 1 \\
\text { hard, torric. }\end{array}$ \\
\hline 2 & $2 c 4$ & $110-125$ & Ismailia & 16 & $\begin{array}{l}\text { - Clay pan, clayey fine, mixed, deep, moderately thin, hai } \\
\text { torric. }\end{array}$ \\
\hline 2 & $2 c 5$ & $125-175$ & Ismailia & 17 & - Claypan, clayey fine, mixed, deep, slightly thick, hard, ts \\
\hline 4 & $2 c 3$ & $360+$ & Ismailia & 18 & $\begin{array}{l}\text { - Claypan, clayey fine, mixed, very deep, very thick } \\
\text { moderately hard, torric. }\end{array}$ \\
\hline 8 & $\mathrm{C} 1$ & $17-110$ & $\begin{array}{l}\text { East Bitter } \\
\text { lake }\end{array}$ & 19 & $\begin{array}{l}\text { - Claypan, loamy, mixed, very shallow, thick, moderately } \\
\text { hard, torric. }\end{array}$ \\
\hline 8 & $\mathrm{C} 2$ & $110-140$ & $\begin{array}{l}\text { East Bitter } \\
\text { lake }\end{array}$ & 20 & - Claypan, clayey fine, mixed, deep, thick, hard, torric. \\
\hline 11 & $\mathrm{Cz} 1$ & $15-40$ & $\begin{array}{l}\text { East Bitter } \\
\text { lake }\end{array}$ & 21 & $\begin{array}{l}\text { Claypan, loamy, mixed, very shaliow, thin, moderately } \mathrm{r} \\
\text { torric. }\end{array}$ \\
\hline 1 & $\mathrm{C} 22$ & $103-160$ & ismailia & 22 & $\begin{array}{l}\text { - Claypan, clayey fine, montmorrillinitic, deep, slightly thic } \\
\text { hard, torric. }\end{array}$ \\
\hline 2 & 2.3 & 91.110 & Ismailia & 23 & $\begin{array}{l}\text { - Claypan, clayey fine, montmorrillinitic, moderately shall, } \\
\text { moderately thin, hard, torric. }\end{array}$ \\
\hline 11 & $\mathrm{Cz} 2$ & $40-120$ & $\begin{array}{l}\text { East Bitter } \\
\text { lake }\end{array}$ & 24 & $\begin{array}{l}\text { Claypan, clayey fine, montmorrilinitic, shallow, moderal } \\
\text { thick, hard, torric. }\end{array}$ \\
\hline 13 & $2 \mathrm{Cz} 2$ & $20-150$ & Sarabium & 25 & $\begin{array}{l}\text { - Claypan, clayey fine, montmorrillinitic, very shallow, ver } \\
\text { thick, extremely hard, torric. }\end{array}$ \\
\hline
\end{tabular}




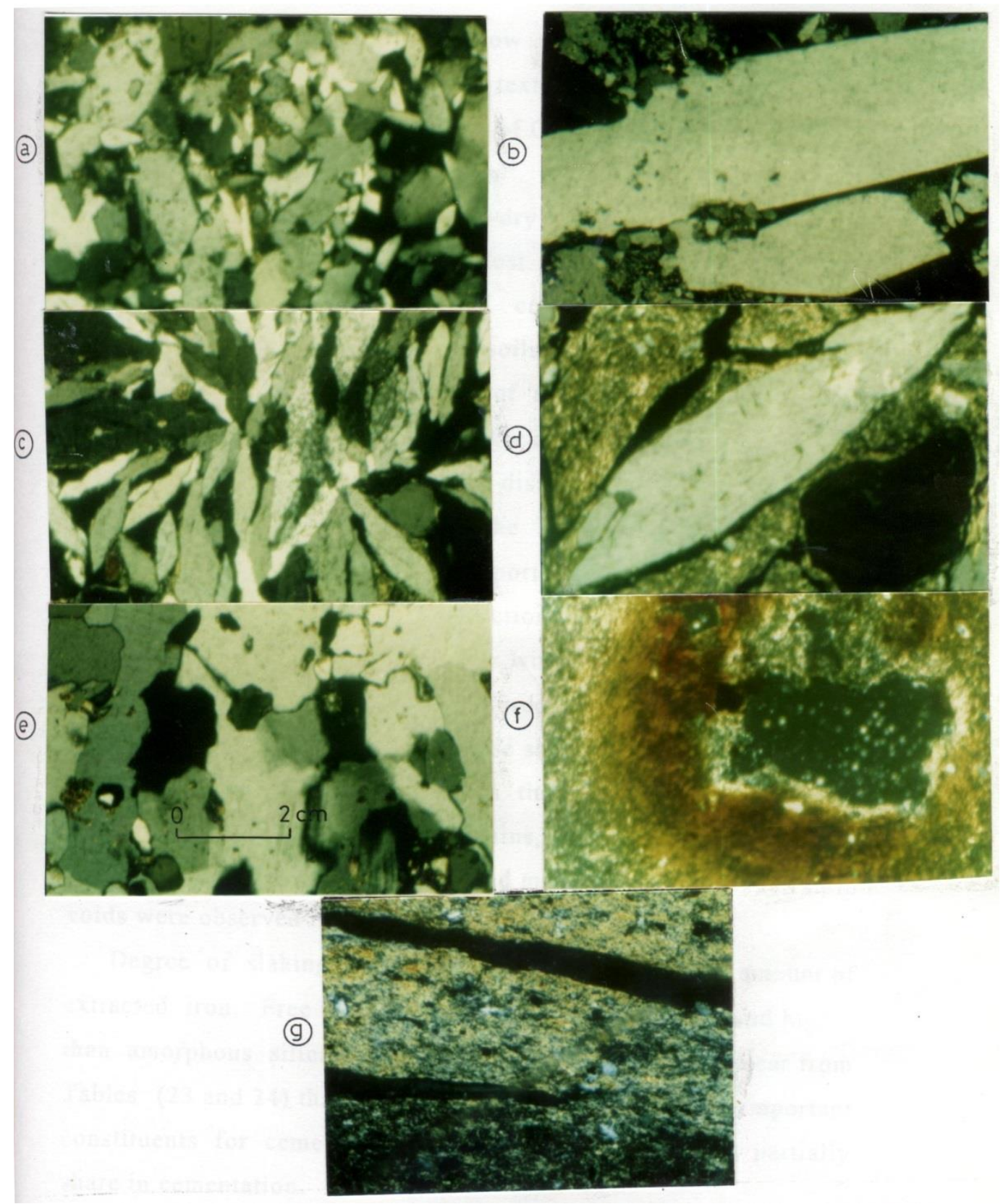

Figure 4 Thin section micrographs of petrogypsipans, cross-polarized light. Line scale $0.27 \mathrm{~mm}$. (a and b) Euhedral gypsum crystals, Cymg2 horizon of prof. No. 14. (c and d) Cym2 horizion of prof. No. 15. (e) Cym3 horizon of prof. No. 16. (f) Cyzm2 horizon of prof. No. 17. (g) Czm3 horizon of prof. No. 17. 
4.1.2 Petrogypsipan, loamy, gypsic, moderately shallow, thin moderately indurated torric: This highly gypsiferous pan is characterized by a very low content of $\mathrm{CaCO}_{3}$, moderately saline and unconfined compressive strength value is 1032 psi for air dry samples (Table 2). It decreased to 216 psi under wet conditions i.e. lost $79 \%$ of its hardness. The mechanism of soil strength reduction with increasing wetness is explained by Pickering and Veneman (1984). They reported that the partial dissolution of the bonding agent between peds and particles, and the reduction of interparticulate friction by films of moisture that import as a lubricant effect.

Results obtained from the thin section examination indicated that the matrix is gyspiferous with many pedogenic euhedral (lens shaped) crystals of gypsum redopsited in the voids. Some large lens shaped gypsum crystals are present in joints (Fig. 4 d). The obtained data from the micromorphological examination and chemical analysis (Table 3) point out that gypsum mineral is playing the major role in the cementation of the pan.

4.1.3 petrogysipan, sandy gypsic, moderately shallow, slightly thick, moderately indurated, torric. This pan is characterized by relatively low bulk density, high gypsum content and relatively low $\mathrm{CaCO}_{3}$ content. The unconfined compressive strength is 1088 psi under air-dry conditions. It decreased to 216 psi, i.e., lost $80 \%$ 
of its strength upon wetting (Table 2). Micromorpholigcal and chemical data show that gypsum is the main cementing agent.

4.1.4 Petrogypsipan clayey, very fine, montmorillonitic, shallow, slightly thick, moderately indurated, torric: Data show that free iron oxides and amorphous silica may play a minor role in cementation. This conclusion is not only based on the amount of cementing agents but also their forms and location in the soil fabric are very important. Micromorphlogical examination revealed that gypsum occurs as powdery forms in voids and joints and is the main cementing agent. The pan has a very dense matrix with some quartz grains embedded in the clay matrix with some argillans along voids and joints and moderately oriented plasma separations. Also Ferrans were observed along vughs. The unconfined compressive strength for arid dry sample is 1225 psi and lost $73 \%$ of its strength upon wetting. Its gypsum content is relatively low (25.4\%) compared to other petrogypsipans and the pan exhibits the second highest compressive strength among this subgroup. The soil strength values are affected not only by changes in water content, but also by changes in soil bulk density, type of clay, types and amounts of dominant cations, types and size of soil structure, number of particle-to particles contacts and amounts and type of organic matter (Habecker et al., 1990).

4.1.5 Petrogypsipan, clayey very fine, montmorillonitic, moderately shallow, thick, moderately indurated, torric: This pan 
is similar to the overlying pan layer (family No. 4.1.4.) in most properties except its depth, thickness and compressive strength (Table 2).

\subsubsection{Petrogypsic ferromanganipan, loamy, mixed, moderately} shallow, very thin, torric: This family is recorded only in East Bitter Lakes areas at various depths and thickness. The morphological examination of pan illustrated that it is yellowish brown, and has many rusty patches and many black spots of manganese and common small gypsum crystals. This very thin pan $(<10 \mathrm{~cm})$ did not slake in water and the effective slaking solutions are HCL and DCB. It contains a relatively high amounts of $\mathrm{Fe}\left(8100 \mathrm{mg} . \mathrm{kg}^{-1}, 6.28 \%\right)$ and $\mathrm{Mn}\left(4200 \mathrm{~m} \cdot \mathrm{kg}^{-1}, 2.27 \%\right)$ in both soil and clay fractions (Table 3 ).

Fabric analysis showed that $\mathrm{Mn}$ is the common in pan matrix containing skeletal grains and filling voids (Fig. 6 c). Some ferrans are present in some voids and coating some grains. Micromorphological observations reveal that Mn associated with iron and gypsum is the main cementing material. The presence of $\mathrm{Mn}$ and $\mathrm{Fe}$ in this pan may be related to the lacustrine deposits which are often considered the soil parent material. Thus, the pan was formed during the old pluvial periods where the climate was more humid than the present time. 


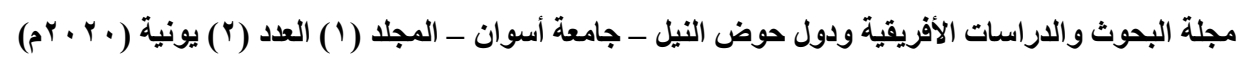
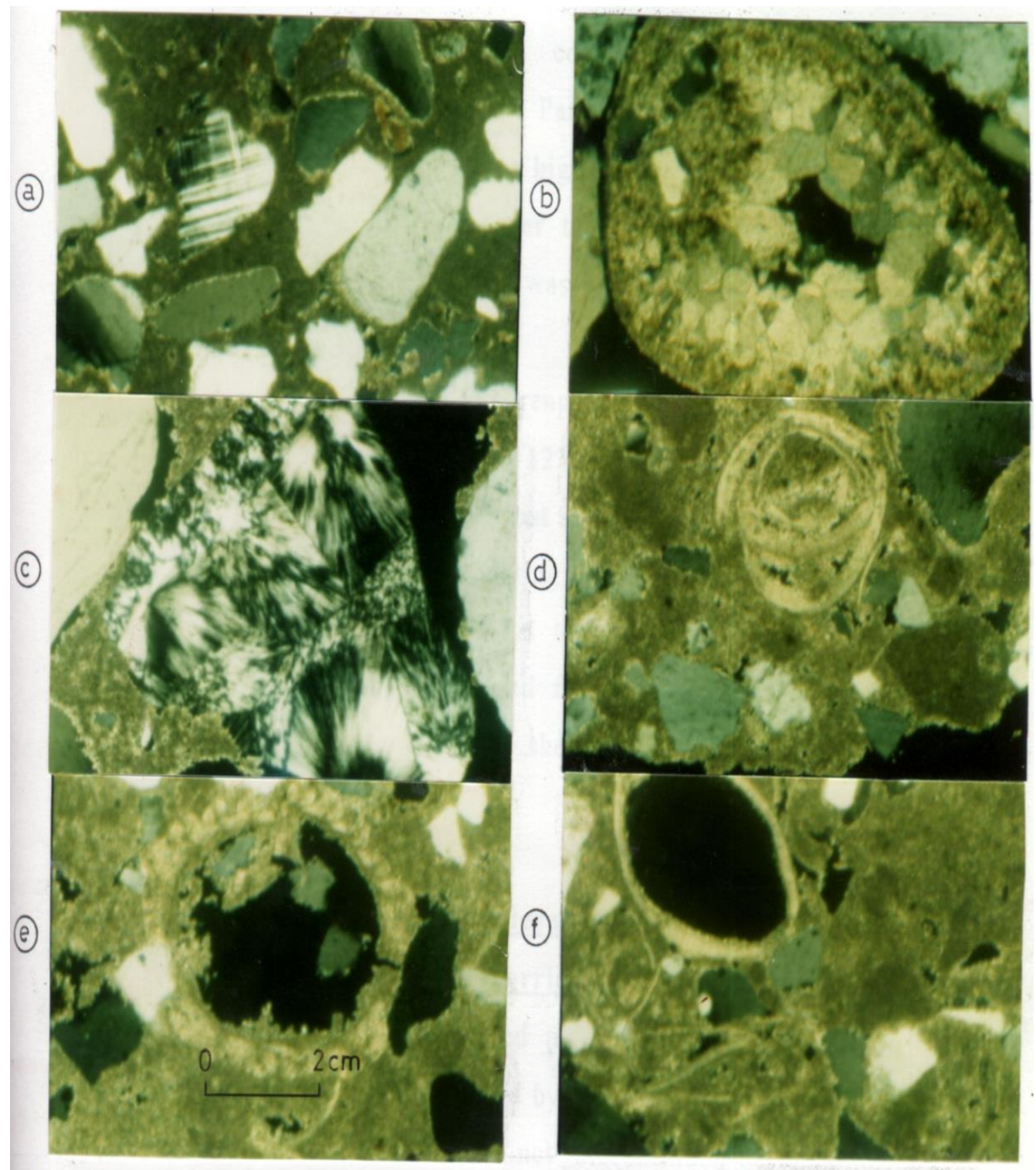

Figure 5 Thin section micrographs of petrocalcipans, cross-polarized light. Line scale $0.27 \mathrm{~mm}$. (a) Non carbonatic matrix with few voids and a thin coating of calcan around quartz and feldspar grains. (b) large calcite crystals with high orientation, prof. No. 3, Ckm4. (c) Chalcedony with well-developed radial shape filling some voids in the carbonatic matrix, prof. No. 9, Ckm2. (d) calcitic fauna of irregular shape in carbonatic matrix, prof. No. 10, Ckm1. (e) Large of calcan around voids in carbonitic matrix, prof. No. 10, Ckm1. (f) Fine grained Calcain voids and filling joints in carbonitic matrix. 


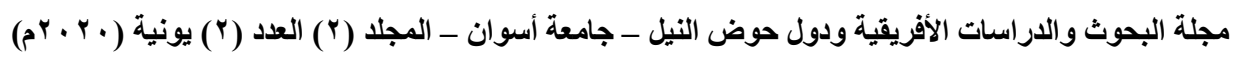

Table 2 Some properties of the pan layers in Suez Canal area

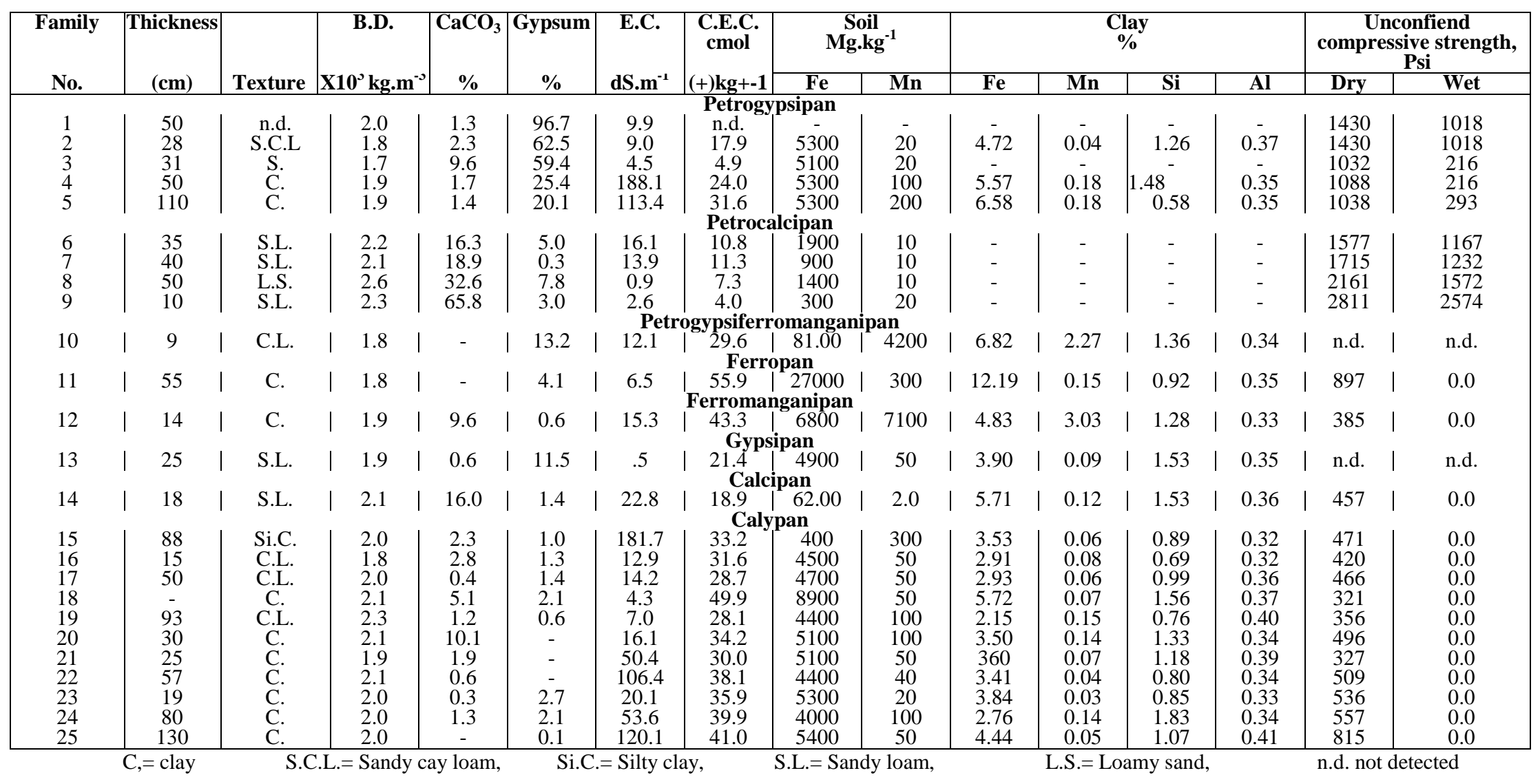




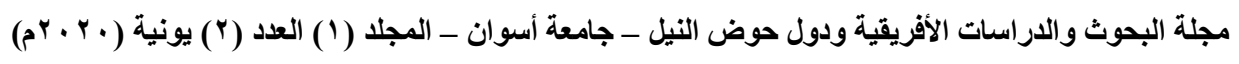

Table 3 Chemical constituents of slaking the pan layers in various solutions.

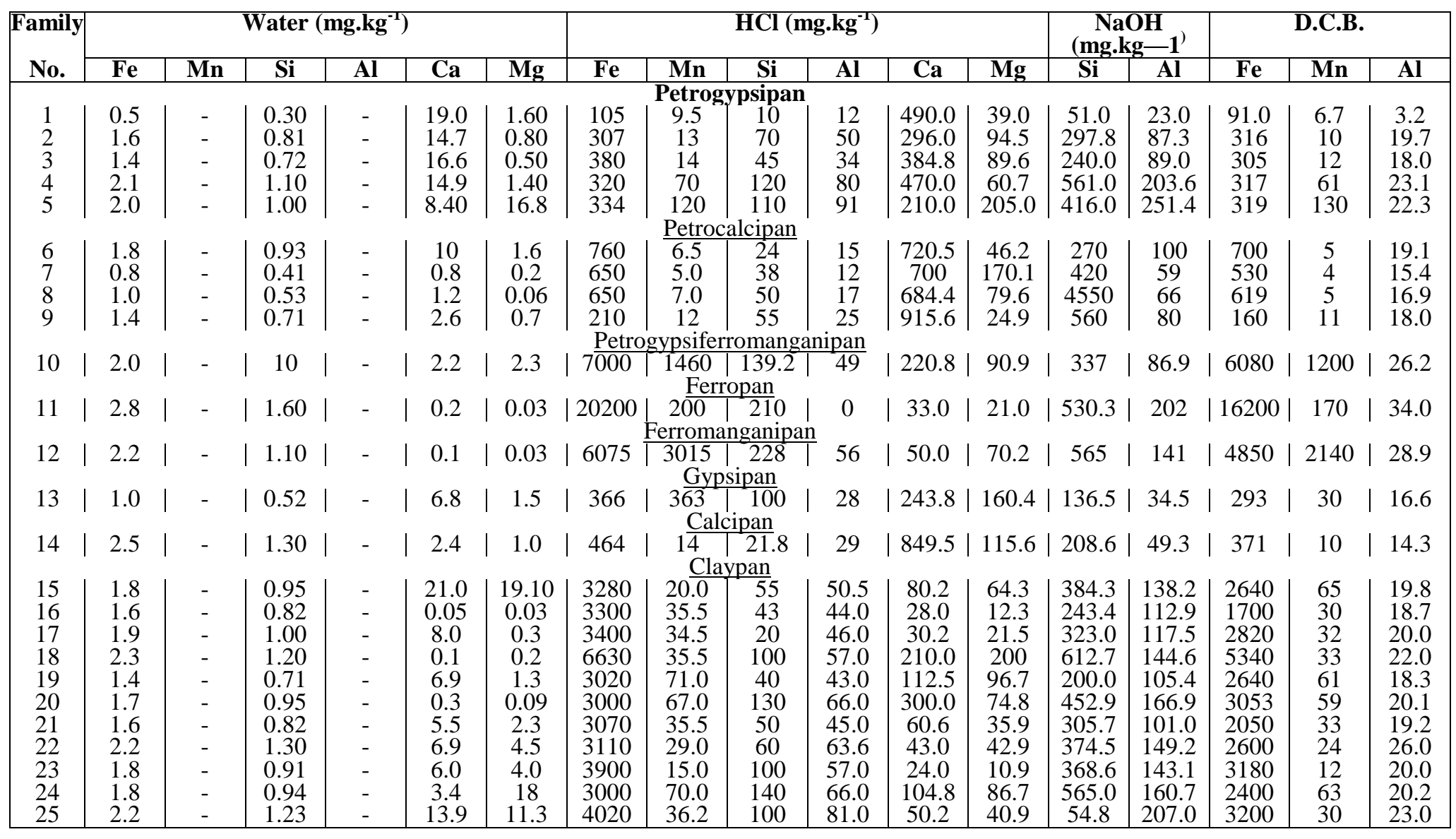

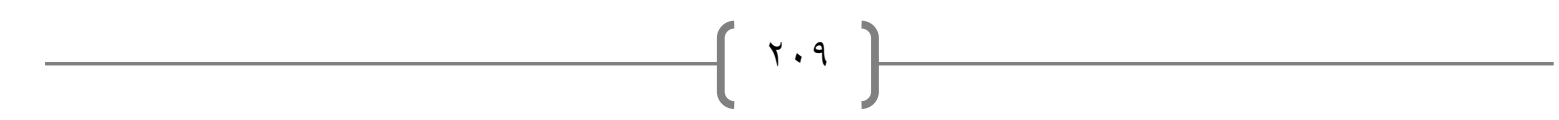




\subsubsection{Petrocalcipan, loamy, mixed, deep, slightly thick, strongly}

\section{indurated, torric:}

This pan is designated as a petrocalcic horizon of secondary $\mathrm{CaCO}_{3}$ in the form of patches, soft and hard lime segregations. Air dry compressive strength is $1577 \mathrm{psi}$, while the compressive strength under wet conditions only decreased to 1167 psi. Therefore, the pan layer lost $26 \%$ of its strength upon wetting. In general, the air-dry compressive strength of petrocalcipans increases as the carbonate content increases, while bulk density does not follow the same trend in most cases.

This pan is strongly indurated in spite of $\mathrm{CaCO}_{3}$ content is not high $(16.3 \%)$. This result may be attributed to the forms and sites of $\mathrm{CaCO}_{3}$ in microfabric and texture of pan. Flach et al. (1969) concluded that the amount of clay affects the amount of $\mathrm{CaCO}_{3}$ required for continuous cementation of the layer. Large amounts of clay require a relatively large amount of $\mathrm{CaCO}_{3}$ in order to bind the clay in a framework of carbonate crystals.

The microfabric analysis confirms that calcite is playing the major role in cementation and induration of the pan (Table 3). The pan matrix is packed closely with few voids and common quartz grains and some plagioclase and microcline grains coated by thin calcans and argillans (Fig. 5 a). Most of the carbonates are present as calcans, crystals chamber and nodules of large calcite crystals with high orientation (Fig. 5 b). 
4.1.8 Petrcalcipan, loamy, mixed, very deep, slightly thick, strongly indurated, torric: This family represents the very deep petrocalcipans with common white patches of secondary carbonates. The air-dry compressive strength value was $1715 \mathrm{psi}$ that decreased to 1232 psi under wet conditions. The micromorphological examination reveals that $\mathrm{CaCO}_{3}$ is the main cementing agent.

\subsubsection{Petrocalcipan, sandy, mixed, moderately shallow, slightly} thick, very strongly indurated, torric: The pan is composed mainly of coarse sand and pebbles strongly cemented by $\mathrm{CaCO}_{3}$. The major features of pan fabric are very dense and closely packed carbonatic matrix with very rare voids. Fine-grained carbonate cementing the skeletal grains occurs as void coating. Chalcedony with well-developed radial shape was recorded in some voids (Fig. 5 c). Fitzpatrick (1984) stated that chalcedony occurs in both very dry and very wet conditions.

4.1.10 Petrocalcipan, loamy, carbonatic, shallow, moderately thin, very strongly indurated, torric: This highly calcareous pan is characterized by very high bulk density and compressive strength and more rigid than all other pan layers. Its strength is 2811 psi for air-dry sample and decreased to 2574 psi for wet sample. The microfabric pan is characterized by carbontic matrix associated with large crystals of highly oriented secondary calcite. There are many calcans coating quartz and lining voids. 
Based on the morphological and micromorphological data, the petrocalcic pan has formed through a process in situ alteration of preexisting limestone. Also, the pedegenic alteration of limestone, as a result of situ dissolution and precipitation of carbonates, has resulted in some changes in the microfabric of the pan. Pedogenic carbonate forms include calcite fauna (Fig. 5 d), large crystals of calcan around voids (Fig. 5 e) and fine grained calcan around void and filling joints.

4.2 Nonpetropan families. Four nonpetropans are identified (Figure 6). All clods of this pan slake when immersed in water. The nonpetropan subgroup contains several kinds of pan families.

\subsubsection{Ferropan, clay, very fine, montmorillonitic, shallow,} slightly thick, extremely hard, torric: This pan has yellow to gray color with many rusty spots and patches, common black spots and contains the highest amounts of free iron oxides in both soil and clay samples among all the studied pan layers (Table 3 ). Fabric analysis shows a fine ferrogenous reddish matrix with many joints, skew planes and chambers with some black mangan in joint planes. Ferrans are observed as plasma separations and along joints and skew planes (Fig. 6 c). Iron oxides are the main cementing agent. This pan is non-indurated despite of its high content of iron oxides in comparison with all other studied layers. This result may be attributed to the very fine texture and the extremely high swelling as well as the nature of iron oxides. Gile 
et al. (1966) reported that more iron oxides are necessary to cement fine-textured soils than coarse textured ones. They added that iron oxides act as a cement in the soil horizon that either contains too little clay, or clay that is too inert to shrink and swell.

\subsubsection{Ferromanganipan, clayey fine, montrmorillonitic} moderately shallow, moderately thin, moderately hard, torric:

This black very thin pan is relatively rich in manganese as a thin film and spots with some rusty mottles. It could be distinguished in the field from black color of organic materials by the fact that $\mathrm{Mn}$ reacts vigorously with $30 \% \mathrm{H}_{2} \mathrm{O}_{2}$, while organic matter reacts only slowly. The concentrations of manganese oxide in both soil (7100 mg. $\left.\mathrm{kg}^{-1}\right)$ and clay fraction (3.03\%) are the highest among pans in Suez Canal region (Table 3). Manganese is a common feature of fabric, which lining voids, coating quartz grains and occurs as granular segregations in fine-grained matrix. Generally, the ferromanganipans are mainly associated with redoximorphic features and cemented by redox accumulations (Fe, Mn) solely or in combination which soil mainly was derived from lacustrine deposits during the old pluvial periods.

\subsubsection{Gypsipan, laomy mixed, shallow, thin, torric : Gypsum} occurs in this pan as spindle shaped graind at different sizes. This form of gypsum is almost of pedogenic origin. This conclusion agrees with Carter and Enskeep (1988) and Reda (1995) that 
showed that pedogenic gypsum can be recognized by euhedral to subhedral spindle-shaped grains.

\subsubsection{Calcipans, loamy, mixed, very shallow, moderately thin,}

hard, torric : This pan is not common in the study area. The morphological examination of pan clods revealed that the pan contains many pebbles, common white spots, soft line segregations and thread of lime. There is few fine-grained calcan lining some voids.

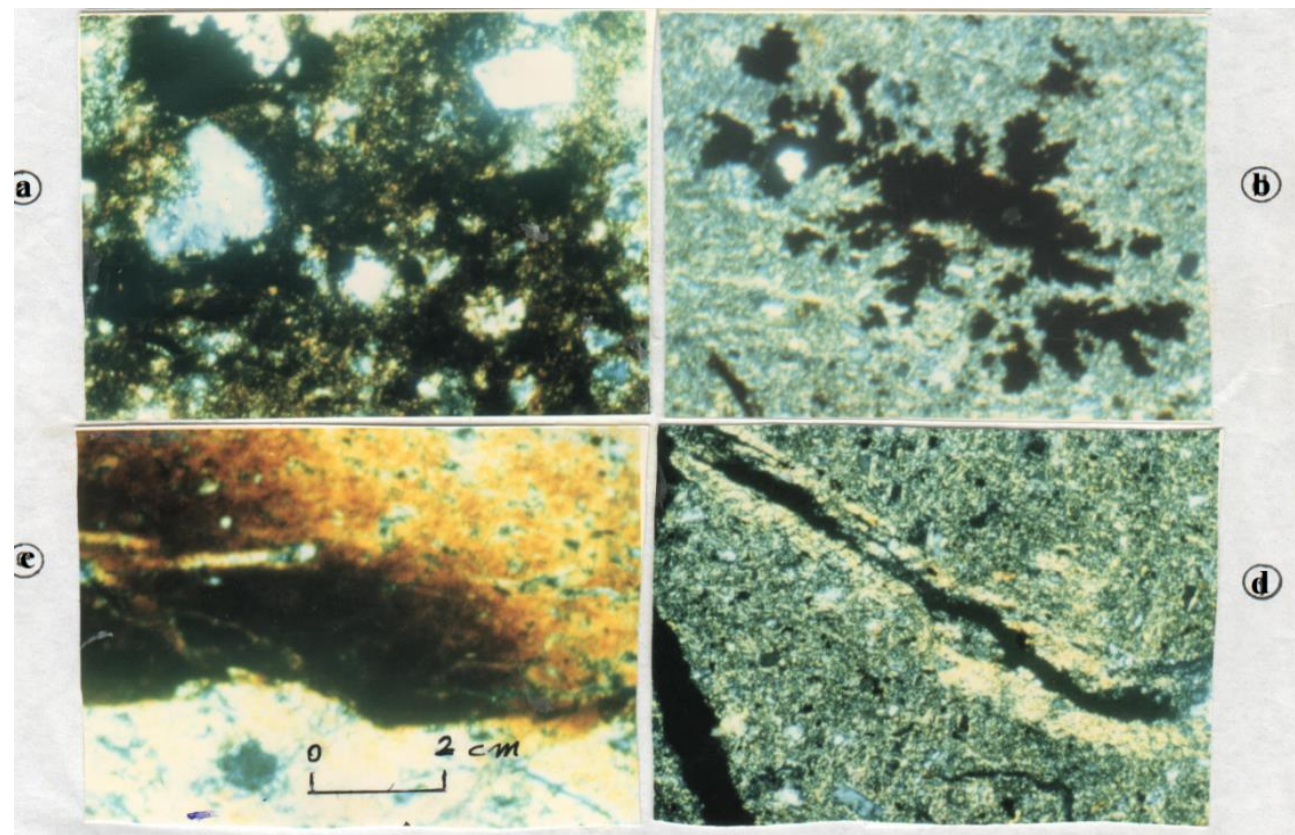

Figure 6 Thin section micrographs of non petropans, and claypans, crosspolarized light. Line scale $0.27 \mathrm{~mm}$. (a) Black mangan coating quartz grains and filling voids. (b) Black granular segregations of manganese oxides with dendritic growth. (c) Ferran of iron oxides as plasma separation along skew planes and joints. (d) Skew plane, strongly oriented argillans (yellow color). 


\subsection{Clay pans}

These pans are the most widespread pans in the Suez Canal area which they are regrouped into 11 families (Table 1). They are found at a depth of 15 to $360 \mathrm{~cm}$ and their thickness varies from 15 to $130 \mathrm{~cm}$. They are variable in certain properties such as depth, thickness, unconfined compressive strength, and salinity. Most of claypans are associated with soils of Typic Haplosalids and Typic Torriorthents. The extracted solution from slaking revealed that $\mathrm{HCl}$ extractable $\mathrm{Fe}$ (3000 to $6630 \mathrm{mg} \cdot \mathrm{kg}^{-1}$ ) is rather higher than DCB extractable Fe (2400 to $5340 \mathrm{mg} \cdot \mathrm{kg}^{1}$ ) (Table 3). These results agree with the extracted iron by DCB solution from the soil (8900 mg. $\mathrm{kg}^{1}$ ) and clay fraction (5.72\%). The bulk density ranged from 1.8 to $2.3 \times 10^{3} \mathrm{~kg} \cdot \mathrm{m}^{3}$. They have a low content of gypsum and $\mathrm{CaCO}_{3}$. Their cation exchange capacity varies between 30.0 to $49.9\left(\mathrm{~mol}(+) \mathrm{kg}^{-1}\right)$; $\mathrm{Mn}$ content is low and salinity varies from saline to extremely saline (Table 2). The air-dry unconfined compressive strength of calypans mainly ranged from 321 to 557 psi, except one pan that reaches 815 psi (Table 2). This exception may be related to the very dense matrix presence of ferran lining vughs and joints and some quartz grains filling some voids.

Most of calypans are characterized by dense matrix, common joints planes, skew planes joints, and skew planes argillans with yellow color and strong orientation (Fig. 7 d). Some claypans show the presence of manganese oxides as localized black 
granular segregations with dendritic growth (Fig. 7 b). Identification of stress oriented argillans and illuvial clay remains a problem particularly in montmorillonitic clay soils where shrinking-swelling characteristics modify the clay coatings. Bullock and Thompson (1985) reported that stress reorganization associated with shrinking and swelling produces a preferred orientation of the clay particles, giving rise to various strained birefringence fabric. Some of stress argillans may closely resemble zones of illuvial clay (Fig. 7 d).

In general, most of the studied claypans in the Suez Canal area are of geogenic rather than pedogenic origin. The reason for this conclusion is the present arid climate and their formation from stratified sediment or from parent material in which there is a marked unconformity within the profile. The most common features of the pan layer are the presence of stress argillan formed as a result of shrinking-swelling process, common joint and skewplanes, mangan and ferran, high clay content, high salinity high swelling potential and high compacting. 

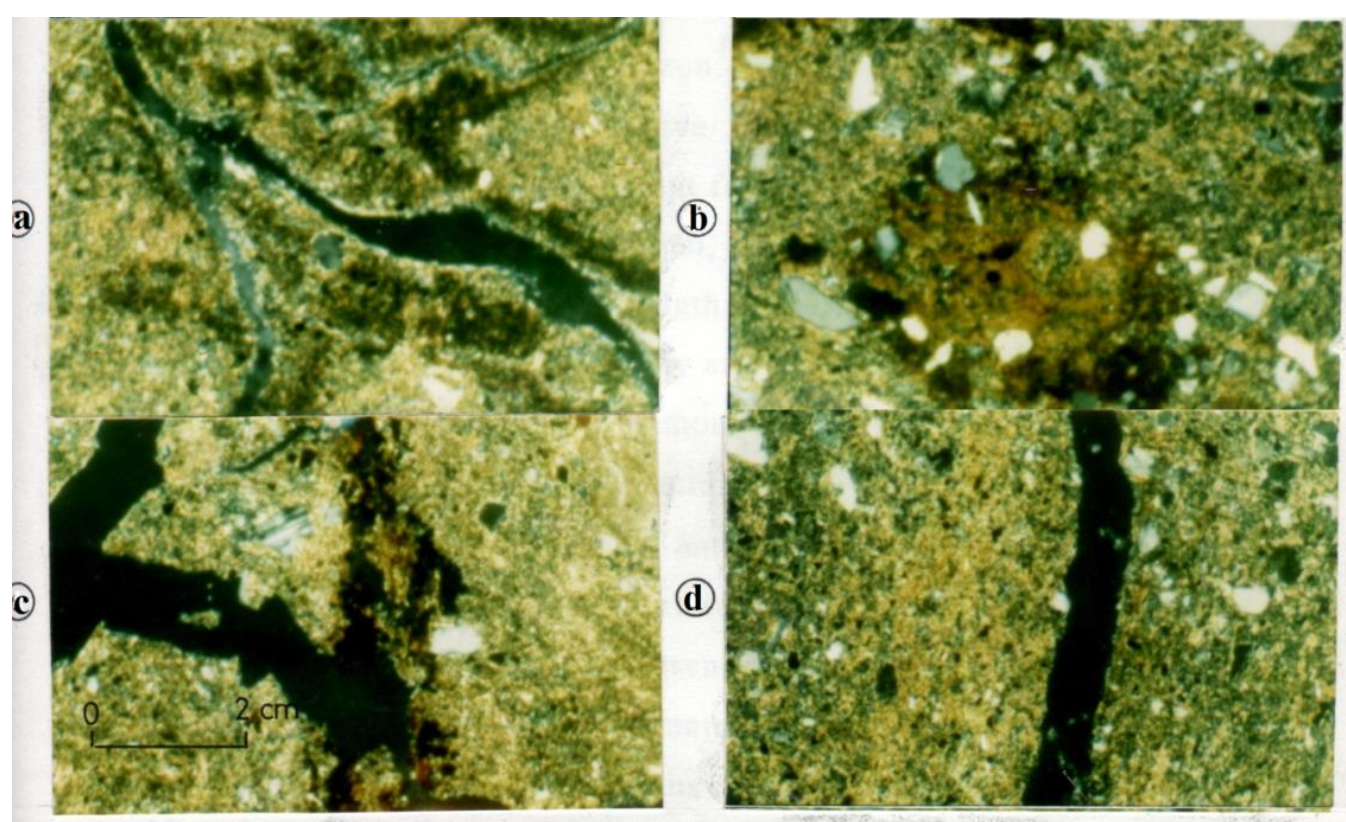

Figure 7 Thin section micrographs of claypans, cross-polarized light. Line scale $0.27 \mathrm{~mm}$. (a) Many skew planes associated with argillans (yellow color) and ferriargillans (dark color), soil prof. No. 2, $2 \mathrm{C} 3$. (b) iron nodules and patches of argillans in clay matrix, soil prof. No. 4, 2C3. (c) Some ferran, mangan and argillans along skew planes, soil prof. No. 8, Cz2. (d) Simple channel argillans with strong orientation, soil prof. No. 1, Cz1.

\section{CONCLUSIONS}

Hardpan layers are thus categorized into 25 families. The most common pans at various sites in the Suez Canal area can be classified into three groups including petropan, non petropan, and clay pan. Petropan layers are indurated and do not slake in water. Petropan group is subdivided according to the type of cement material into three main subgroup; petrogyspipan, petrocalcipan and petrogypsiferromanganipan. Ten pan families are distinguished within the petropan group; however, four pan families are distinguished within the nonpetropan group. Clay 
pans are the most widespread pans in the Suez Canal area which they are regrouped into 11 families. Most of the investigated claypans in the study area are of geogenic rather than pedogenic origin.

This proposed classification identifies different types of pan layers which vary in their texture, mineralogy, depth thickness, hardness, and humidity range. Such information will also contribute to recommend adequate guidance for soils of best agricultural use without reacting to their incorrect hypotheses. 


\section{REFERENCES}

Abdel-Dayem S, Abdel-Gawad S, Fahmy H 2007. Drainage in Egypt: A story of determination, continuity, and success. Irrigation and Drainage systems 56:101-111

Al Masud M, Nurun NM, Abul Kalam A 2014. Impacts of Water logging on Biodiversity - Study on South- western Region of Bangladesh. IOSR Journal of Environmental Science, Toxicology and Food Technology (IOSRJESTFT) 8 (9):20-27. doi:10.9790/2402-08912027

Black, C.A., 1965. Methods of Soil Analysis. I. Physical and miceralogical properties including statistics of measurement and sampling. American Soc. Of Agronomy, Inc., Publisher, Madison, WI., U.S.A.

Brewer, R., 1976. Fabric and Mineral Analysis of Soils. Kriegen Huntington, N.Y.

Bullock, P. and Thompson, M.L., 1985. Soil Micromorphology and Soil Classifica-tion. Soil Sci. Soc. Of Am. 677S. Segoe Road, Madison, Chapter 2, 17-45.

Carter, B.J., and Inskeep, W.P., 1988. Accumulation of pedogenic gypsum in Western Oklahoma Soils. Soil Sci. Soc. Am. J. 52: 1107-1113.

El-Araby, A.M.A. and Hussein, S.A., 1984. Formation and composition of some Caliche deposits in the Western Desert of Egypt. Egypt. J. Soil Sci., 24: 31-40.

El Bastawesy M, Ramadan AR, Faid A, El Osta M .2013. Assessment of waterlogging in agricultural mega projects in the closed drainage basins of the Western Desert of Egypt. Hydrol Earth Syst Sci 17:1493-1501

El-Fayoumy, I.D., 1968. Geology of ground water supply in the region of the Nile Delta. Ph.D. Thesis, Fac. Sci., Cairo Univ., Egypt. 
El-Mowelhi, N.M., and Hamdi, H., 1975. Pans in the Soils of Egypt. Silver Jubilee of the Soil Sci. Soc. Of Egypt: 1.

Fitzpatrick, E.A., 1984. "Micromorphology of Soils". 11 New Fetterlane, London.

Flach, k.w.; Nettleton, W.D.; Gile L.H., and Cady, J.G., 1969. Pedocementation: Induration by silica, carbonates and Sesquiorixes in the Quaternary. Soil Sci. 107: 442-453.

Franklin, J.A. and Dusseault, M.B., 1989. "Rock Engineering" McGraw-Hill, Inc., London.

Gendy, E.N., 1976. Studies on hardpan layers in some Egyptian soils. M.Sc. Thesis, Fac. Agric., Assiut Univ., Egypt.

Gile, L.H.; Petroson, F.f. and Grossman, R.B., 1966. Morphological and gentic sequences of carbonate acumulation in desert soils. Soil Sci. 101: 347-360.

Habecker, M.A.; McSweeney, K. and Madison, F.W., 1990. Identification and genesis of fragipans in Ochrept of North Central Wisconsin. Soil Sci. Soc. Am. J., 54: 139146.

Hashimato, I., and Jackson, M.L., 1960. Rapid dissolution of allophane and kaolinite-halloysite after dehydration. Clays. Clay Minerals, 7: 102-113.

Hashimoto, I. and Jackson, M. L. (1960) Rapid dissolution of allophane and kaolinitehalloysite after dehydration: in Clays and Clay Minerals, Pergamon Press, New York, pp. $10 \% 113$.

Jackson, M.L., 1975. "Soil Chemical Analysis". Adv. Course, Publ. By the author, Madison Wisconsin, U.S.A.

Konukcu F, Gowing JW, Rose DA .2006. Dry drainage: A sustainable solution to waterlogging and salinity problems in irrigation areas? Agr Water Manage 83:1-12 
Masud, M.M., N.N. Moni, H. Azadi and S. Van Passel 2018: Sustainability impacts of tidal river management: Towards a conceptual framework. - Ecological Indicators 85: 451- 467, doi:10.1016/j.ecolind.2017.10.022

Mckeage, J.A. and Sprout, P.N., 1975. Cementyed sub-soils (duric horizons) in some soils of British Columbia. Can. J. Soil Sci. 55: 189-203.

Najeeb U, Bange MP, Tan DK, Atwell BJ (2015) Consequences of waterlogging in cotton and opportunities for mitigation of yield losses. AoB PLANTS 7 (plv080). doi:10.1093/aobpla/plv080

Omran, E. El. (1996). Mineralogical and chemical properties of indurated layers in soils of Suez Canal region. M.Sc. Thesis, Suez Canal Univ., Faculty of Agric., Soil Dept., Ismailia.

Omran ESE (2009) A Proposed Simplified Method to Improve Land-use Mapping Accuracy. Agricultural Research Journal 9 (3):123- 132.

Omran E-SE (2016) A stochastic simulation model to early predict susceptible areas to water table level fluctuations in North Sinai, Egypt. The Egyptian Journal of Remote Sensing and Space Science 19 (2):235-257

Omran ESE (2017) Evolving waterlogged identification system to assess spatiotemporal impact of the new Suez Canal corridor, Egypt. Journal of Coastal Conservation 21 (6):117

Omran EE (2020a) Assessment of Groundwater Overpumping Impact on the Waterlogging Development in El-Farafra Oasis, Egypt. In: Negm A, IWASAKI, ELBEIH5 (eds) Sustainable Water Solutions in the Western Desert, Egypt The Handbook of Environmental Chemistry, Springer, Cham 
Omran EE (2020b) Detecting and Controlling the Waterlogging in El-Dakhla Basin. In :Negm A, IWASAKI, ELBEIH5 (eds) Sustainable Water Solutions in the Western Desert, Egypt The Handbook of Environmental Chemistry, Springer, Cham

Page, A. L., R. H. Miller and D. R. Keeney (Ed., 1982). Methods of soil analysis; 2. Chemical and microbiological properties, 2. Aufl. 1184 S., American Soc. of Agronomy (Publ.), Madison, Wisconsin, USA

Pickering, E.W. and Veneman, P.L.M. 1984. Strength characteristics of three indurated horizons in Massachusetts. Soil Sci. Soc. Am. J. 48: 133-137.

Reda, M. and Hussein, M. 1995. Clay minerals assemblages of the soils of Dakhla and their relation to geological formations. Fayoum J. Agric. Res. Dev., Vol. 9, No. 2.

Reda, M. (1999). Soils and desertification processes in Saudi Arabia, The third conference on desertification and environmental studies beyond year 2000, Riyadh, King Saud University.

Richards, L.A. (Ed.), 1954. Diagnosis and improvement of saline and alkali soils. U.S.D.A. Handbook No. 60.

Roy, L.D., 1963. Soil compacting problems. Our soil and their management: 221-239, Printic Hall., U.S.A.

Said, R., 1990. The geology of Egypt, Balkema, Rotterdam, Molom, 734 p.

Shata, A.A. and Shata, A.As., 1997. Regional geogenetic soil processes in Egypt. Egyptian Journal of Soil Sci., I, 37.

Shata, A.As., 1978. Genesis, formation and classification of the soils of Ismaelya Canal between Belbes and Ismaelya including wadi Tumilat. M.Sc. Thesis, Fac. Agric., Zagazig Univ., Egypt. 
Soil Survey Staff., 1951. Soil Survey Manual. U.S.D.A., Washington.

Soil Survey Staff. 2014. Keys to soil taxonomy, 2014. US Gov. Print. Office, Washington, DC.

Winter, E., and Simonson, R.W., 1955. The Sub-soil. Advance in Agronomy, Academic Press, New York, 3: 1-92 